\title{
Least restrictive alternative - advance statements and the new mental health legislation
}

Proposals for new mental health legislation make the case for using the 'least restrictive alternative' (Scottish Executive, 2001) and the 'least restrictive environment' (Department of Health \& Home Office, 2000) as guiding principles in deciding the management and treatment of the patient. This appears to be the case made for introducing compulsory treatment in the community. The patient living in the community, while maintained on medication, rather than the hospital would appear to be defined as on the 'least restrictive alternative'. This, however, takes only a limited approach to what is 'restrictive', which should be interpreted more widely, including the patient's view as well as that of clinicians and policy makers. Thus, a patient may see it as less restrictive during an acute phase to be in hospital and not on medication, than in the community but on medication. It is likely, given our knowledge of patients' attitudes to medication (Eastwood \& Pugh, 1997), that many patients will prefer to be on oral medication rather than depot, which they see as less restrictive.

If the least restrictive alternative is to be a formative principle in providing ongoing care under new mental health legislation, then consideration has to be given as to how it is to be incorporated. There appears to be no intention to enshrine a hierarchy of restrictiveness in legislation, although this has happened in some American states; in Michigan seclusion is considered less restrictive than physical restraint, which is less restrictive than enforced medication (Slovenko, 1989). The pro forma for making an advance directive, offered by the American Bazelon Center for Mental Health Law (see http// www.bazelon.org/adudir.html), invites people to select their personal hierarchy of these same options. This needs to be seen in the context of the individual's right in some American states to refuse medication in certain circumstances, even when detained (Atkinson \& Patterson, 2001).

Guidelines might, however, be given in any Code of Practice that accompanies the new Acts and could indicate whether the least restrictive alternative is an individual or policy formulation. Although it is unlikely that many practitioners or patients in the UK would share the hierarchy of restraint formalised in Michigan, it does highlight the subjective dimension of 'restrictive'.

A formulation of the least restrictive alternative for a particular patient requires knowledge of that patient's individual perspective. The time of detention may not be most appropriate to determine this, given that both the patient's mental state and the detention itself may be experienced as coercive, restrictive and forcing the patient into choices he/she did not want to make in the first place. This may be particularly true if in-patient treatment issues are to be included in the 'least restrictive', as well as treatment plans devised at the time of discharge. If detained patients are not to be able to refuse medication then any commitment to the least restrictive alternative on an individual rather than policy level is already limited.

Ideally, patients' views would be known before detention and since advance statements/agreements are being proposed in the new legislation (Scottish Executive, 2001; Department of Health \& Home Office, 2000), it may prove useful to see these two proposals in combination. Thus, the concept of restrictive practice could be discussed with patients in a context away from the actual detention, written into an advance statement and incorporated into management plans from the outset. Clearly this will only apply to patients already in contact with psychiatric services. This, no doubt, already happens in many consultations when agreeing a treatment or management plan with a patient, even if not couched in these terms. In the same way, it is likely that wishes expressed in advance statements might be reinterpreted as the least restrictive alternative. Indeed, it could be argued that if a patient makes an advance statement, by definition, this has to be 'least restrictive' because it is what the patient has chosen.

As well as considering the length and location of confinement, Gostin (2000) argues that the Human Rights Act requires determination of what constitutes detention to consider 'the use of force or deception, the person's resistance to or displeasure with, restraint and treatment [and] the person's mental capacity'. Challenge under the Human Rights Act to the use of restrictions, including in the community, may rest on the issue of proportionality.

Although the use of advance statements/agreements will be influenced by ethics, resources (Halpern \& Szmukler, 1997) and legal implications (Dawson et al, 2001), there does appear, however, to be a growing commitment to them, as evidenced by the mental health law reviews in the UK. A recent New York State initiative, which is spending US\$1 million on an education campaign advising how to complete a mental health advance directive (Monahan et al, 2001), demonstrates a commitment to them in a country from which, for better or worse, many social policy initiatives are imported into the UK.

It is probably a mistake to assume that the least restrictive alternative will be a static concept for patients and it should be expected that it might change as a patient experiences different forms of management and control. As with advance statements, patients' choices are influenced by what they have experienced. Patients may find a choice more restrictive or upsetting than expected; for example, if refusing medication were to 
lead to physical restraint. Staying in the community may bring unexpected restrictions. Some of the conditions placed on patients on a community care order are highly restrictive, to the point where institutional living may give more day-to-day freedom (Atkinson et al, 2002). Community care orders were introduced in Scotland in the Mental Health (Patients in the Community) Act 1995. Following the restriction of leave of absence to 12 months, it allowed conditions to be put on patients living in the community, but did not allow enforced medication. The committee set up to review the 1984 Mental Health Act in Scotland, under the chairmanship of the former Secretary of State for Scotland, Rt Hon. Bruce Millan (Scottish Executive, 2001), recommended the abolition of the community care order in favour of a community order, thus replacing a less restrictive order with a potentially more restrictive one.

As with advance statements, we might expect that resources will have an influence on least restrictive choice. Refusing medication may result in increased hospital stay, as described in relation to advance directives (Halpern \& Szmukler, 1997). How far, however, is it appropriate to impose restrictive choices on a patient because of lack of resources or political inability to deliver choices? The Mental Health Acts already state that patients should be detained at the minimum level of security necessary. Nevertheless, there is a substantial number of patients detained in the State Hospital at Carstairs whom everyone agrees does not require maximum security, yet there is nowhere to which these patients can be discharged (Mental Welfare Commission for Scotland, 1999). Despite Scottish Parliament plans to develop medium secure units, local politicians in Scotland have supported local objections to having such units within their constituencies. Lack of a less restrictive facility would almost certainly not lead to someone being fully discharged from a more restrictive one ( $R$. $v$. Camden and Islington Health Authority ex parte K, 2001) but still requires consideration as a breach of the principles enshrined in the new legislation.

Lack of resources to implement one of the principles suggested for the new Scottish Act would run counter to another of the recommended fundamental principles, namely reciprocity, which balances taking away a person's freedom with the provision of good care. Concern has been expressed, however, that if the 'best' care is provided for patients who are detained then this provides a perverse incentive to detain people who might otherwise have been treated as voluntary patients. This, of course, would then be in direct contradiction to the principle of a least restrictive alternative. One of the fundamental principles articulated by the Millan Committee (Scottish Executive, 2001) as underpinning the new Act is patient autonomy and it is here that least restrictive alternative and advance statements could be envisaged as coming together to support this principle.

\section{Declaration of interest}

J.M.A. is a grant holder for funds from the Nuffield Foundation to research advance directives in mental health care. She is an unpaid director of the National Schizophrenia Fellowship (Scotland). H.G. is a research assistant, working for J.M.A. on a project funded by the Nuffield Foundation.

\section{References}

ATKINSON, J. M., GARNER, H. C., GILMOUR,W. H., et al (2002) The introduction and evaluation of Community Care Orders. Journal of Mental Health, 11, in press.

— \& PATTERSON, L. E. (2001) Review of Literature Relating to Mental Health Legislation. Edinburgh: Scottish Executive.

DAWSON, J., KING, M., PAPAGEORGIOU, A., et al (2001) Legal pitfalls of psychiatric research. British Journal of Psychiatry, 178, 67-70.

DEPARTMENT OF HEALTH \& HOME OFFICE (2000) Reforming the Mental Health Act. London: Department of Health \& Home Office.

EASTWOOD, N. \& PUGH, R. (1997) Long-term medication in depot clinics and patients' rights: an issue for assertive outreach. Psychiatric Bulletin, 21, 273-275.

GOSTIN, L. O. (2000) Human rights of persons with mental disabilities; the

European Convention of Human Rights International Journal of Law and Psychiatry, 23, 125-159.

HALPERN, A. \& SZMUKLER, G. (1997) Psychiatric advance directives: reconciling autonomy and nonconsensual treatment. Psychiatric Bulletin, 21, 323-327.

MENTAL WELFARE COMMISSIONFOR SCOTLAND (1999) Annual Report. Edinburgh: Mental Welfare Commission for Scotland.

MONAHAN, J., BONNIE, R. J., APPELBAUM, P. S., et al (2001) Mandated community treatment: beyond outpatient commitment. Psychiatric Services, 52, 1198-1205.

SCOTTISHEXECUTIVE (2001) New Directions: Report on the Review of the Mental Health (Scotland) Act 1984 (SE / 2001/56).

SLOVENKO, R. (1989) Misadventures of psychiatry with the law. Journal of Psychiatry and the Law, 17, 115-156.

R. v. Camden and Islington Health Authority ex parte K (2001) Commentary: mental health: health and social services authorities'duties to provide after care needed to implement tribunal discharge decision. Medical Law Review, 9, 180-184.

*Jacqueline M. Atkinson Senior Lecturer Helen C. Garner Research Assistant, Department of Public Health, University of Glasgow, 1 Lilybank Gardens, Glasgow G12 8RZ 